\title{
Infections of Ligula intestinalis on Freshwater Fish in Kars Plateau of North-Eastern Anatolia, Turkey
}

\author{
Türkiye’nin Kuzey Doğu Anadolu Bölgesi Kars Platosundaki Tatlı Su Balıklarında Ligula \\ intestinalis Enfeksiyonları
}

\author{
Mükremin Özkan Arslan, Muhittin Yılmaz², Gencay Taşkın Taşçı1 \\ 'Department of Parasitology, Kafkas University Faculty of Veterinary Medicine, Kars, Turkey \\ ${ }^{2}$ Department of Bioengineering, Sinop University Faculty of Engineering and Architecture, Sinop, Turkey
}

\section{ABSTRACT}

Objective: This study was conducted to determine the prevalence of Ligula intestinalis and infections caused by these on freshwater fish in rivers and streams in the Kars plateau of north-eastern Anatolia, Turkey.

Methods: This research was conducted between April and July 2011. Fish samples were caught via a casting net and an electro-shocker. The samples were immediately examined to determine the prevalence of $L$. intestinalis plerocercoids.

Results: In this research, 310 stream fishes were studied to determine the prevalence of $L$. intestinalis plerocercoids. Detected fishes included 55.8\% Capoeta capoeta, 24.2\% Squalius cephalus, 11.0\% Alburnus filippii, 5.8\% Barbus plebejus lacerta, and 3.2\% Alburnoides bipunctatus. L. intestinalis plerocercoids were found in 2.6\% (8/310) of the examined fishes. The percentage of this parasite was found to be $38.9 \%$ (7/18) on B. plebejus lacerta and $0.6 \%(1 / 173)$ on C. capoeta. L. intestinalis plerocercoids were not observed on the other three fish species (S. cephalus, A. filippii, and Al. bipunctatus).

Conclusion: In this study, L. intestinalis plerocercoids were reported for the first time in the Kars stream and its distributaries on the Kars plateau in north-eastern Anatolia, Turkey. (Turkiye Parazitol Derg 2015; 39: 218-21)

Keywords: Ligula intestinalis, ligulosis, freshwater fish

Received: 11.02.2015

Accepted: 09.07.2015

\section{Öz}

Amaç: Araştırma Türkiye'nin Kuzey Doğu Anadolu Bölgesi'nde bulunan Kars Platosunda yer alan dere ve çaylardaki tatlı su balıklarında Ligula intestinalis parazitlerinin yaygınlığını ve bunların neden olduğu enfeksiyonları bildirmek amacıyla yapıldı.

Yöntemler: Çalışma Nisan-Temmuz 2011 tarihleri arasında yürütüldü. Materyali oluşturan balık örnekleri serpme ağ ile avlamak süratiyle yakalandı. Ligula intestinalis pleroserkoidleri yönünden avlama sonrası hemen parazitolojik olarak incelendi.

Bulgular: Araştırmada 310 adet akarsu balığı Ligula intestinalis plerocercoidi yönünden incelendi. Bu balıkların \%55.8'ini Capoeta capoeta, \%24.2'sini Squalius cephalus, \%11.0'ini Alburnus filippii, \% 5.8'ini Barbus plebejus lacerta ve \%3.2'sini ise Alburnoides bipunctatus türleri oluşturdu. İncelenen balıkların \%2.6 (8/310)'ında L. intestinalis plerocercoidi saptandı. Bu parazitin görülme oranı Barbus plebejus lacerta'da \%38.9 (7/18) ve Capoeta capoeta'da \%0.6 (1/173) olarak bulundu. Diğer üç balık türü olan Squalius cephalus, Alburnus filippii ve Alburnoides bipunctatus'ta ise cestod larvasına rastlanmadı.

Sonuç: Bu çalışmada Kars Platosunda yer alan Kars Çayı ve kollarındaki tatlı su balıklarında L. intestinalis plerocercoidleri ilk olarak bildirildi. (Turkiye Parazitol Derg 2015; 39: 218-21)

Anahtar Kelimeler: Ligula intestinalis, ligulosis, balık

Geliş Tarihi: 11.02.2015

Kabul Tarihi: 09.07.2015

Address for Correspondence / Yazışma Adresi: Dr. Mükremin Özkan Arslan. E.posta: ozkanarslan@gmail.com DOI: 10.5152/tpd.2015.4168

CCopyright 2015 Turkish Society for Parasitology - Available online at www.tparazitolderg.org

CTelif hakkı 2015 Türkiye Parazitoloji Derneği - Makale metnine www.tparazitolderg.org web sayfasından ulaşılabilir. 


\section{INTRODUCTION}

One of the most important health problems observed in fish farming is parasitic diseases, especially cestodes parasites. Ligula intestinalis is widely encountered in freshwater in the Northern Hemisphere, which includes Turkey. This parasite causes economic loss in the fish industry. L. intestinalis instances to the skin, connective tissue, and respiratory system This helminth species is important in terms of fish health and causes ligulosis (1-3). L. intestinalis categorized in the Diphyllobothrium family is a cestode that reaches $28 \mathrm{~cm}$ in adults and $40 \mathrm{~cm}$ in plerocercoids. The final host organism of the parasite is waterbirds. Coracidium in eggs excreted with the feces of waterfowl are taken by Crustacea (Cyclops, Diaptomus), which is the first intermediate host. Coracidium transforms into procercoids by penetrating the internal wall of these arthropods and by locating into the body tissue. Freshwater fish, which are the second intermediate host of $L$. intestinalis, ingest procercoids by eating the first intermediate hosts. Procercoids, locating in the body cavity by piercing through the intestinal wall of the fish, transform into plerocercoids. Plerocercoids transform into the adult form in birds that eat the second intermediate host fish of the main host waterfowl $(1,3)$.

Plerocercoids, filling the body cavity of the fish, cause pressure on the organs in the abdominal cavity. As a result of this, the heart is pushed toward the front, the liver becomes deformed, and abdominal wall thinning, loss in weight, and parasitic castration caused by suppressing the development of the gonads are seen. Death occurs in severe infections. Fishes infected by $L$. intestinalis plerocercoids are not able to swim properly, and their bellies are tumid; furthermore, it can be seen that bellies burst and the parasites get out (3-7).

In studies related to fish parasites, it was reported that $L$. intestinalis has been observed in many parts of lakes, dams, and rivers worldwide and in Turkey at varying rates between $0 \%$ and $97 \%$ $(2,4,5,8-13)$. However, to date, no research has been conducted that deals with this parasite on freshwater fish densely populated rivers in the north-eastern Anatolia region of Turkey.

Therefore, this research was made to determine the prevalence of $L$. intestinalis and infections caused by these on freshwater fish in river and stream in the Kars plateau in north-eastern Anatolia, Turkey.

\section{METHODS}

The study was conducted in 2011 between April and July in the Kars stream and itsbranches. Samples of fish were captured by casting a net and an electro-shocker. The fish samples were taken from Kırmızı Köprü on Kağızman Road, Aksu village of Susuz, Akçalar on Arpaçay Road, and Telek village of Arpaçay.

In the study, 310 fish families in Cyprinidae were examined to determine the prevalence of $L$. intestinalis plerocercoids. A total of 310 fish belonging to 5 different fish species, including a total of 173 Capoeta capoeta, 75 Squalius cephalus, 34 Alburnus filippii, 18 Barbus plebejus lacerta, 10 Alburnoides bipunctatus, were studied. After the fishes were caught alive, we waited for them to die by themselves. They were examined for the parasite of $L$. intestinalis plerocercoids. The abdomens of the fishes were dissected from the urogenital region to the pharyngeal region. The body cavity of the fishes was macroscopically examined for determining the prevalence of $L$. intestinalis plerocercoids. Collected plerocercoids were stored in $10 \%$ formaldehyde in the laboratory of parasitology department of Kafkas University. Additionally, fish species were determined according to literature (14).

\section{RESULTS}

In this research, 310 stream fishes were studied to determine the prevalence of $L$. intestinalis plerocercoids. In total, $173 \mathrm{C}$. capoeta, 75 S. cephalus, 34 A. filippii, 18 B. plebejus lacerta, $10 \mathrm{Al}$. bipunctatus were examined. In total, $2.6 \%$ (8/310) L. intestinalis plerocercoids were detected among the examined fishes. The percentage of this parasite was found to be $38.9 \%(7 / 18)$ on $B$. plebejus lacerta and $0.6 \%(1 / 173)$ on C. capoeta. L. intestinalis plerocercoids were not observed on the other three fish species: S. cephalus, A. filippii, and Al. bipunctatus.

While 7 out of the 8 fish were infected by one L. intestinalis plerocercoid, five plerocercoids were found in infected B. plebejus lacerta. This parasite was detected a lot on B. plebejus lacerta. Ligulosis was mostly prevalent in the Telek (carci) stream of Arpaçay town (Kars/Turkey). B. plebejus lacerta heavily infected by this parasites were caught in this river (Table 1).

\section{DISCUSSION}

Considering nutritional problems as a result of the growing world population, fish products have become more important. Fish and fish products are important for human nutrition.

Table 1. Distribution of Ligula intestinalis on freshwater fish through the streams in the Kars plateau of north-eastern Anatolia, Turkey

\begin{tabular}{|l|c|c|c|c|c|}
\hline \multirow{2}{*}{ Stream Name (Station Name) } & \multicolumn{4}{c|}{ Fish species, x/n* (Infection Rate) } \\
\cline { 2 - 5 } & $\begin{array}{c}\text { Capoeta } \\
\text { capoeta }\end{array}$ & $\begin{array}{c}\text { Squalius } \\
\text { cephalus }\end{array}$ & $\begin{array}{c}\text { Barbus } \\
\text { plebejus lacerta }\end{array}$ & $\begin{array}{c}\text { Alburnoides } \\
\text { bipunctatus }\end{array}$ & $\begin{array}{c}\text { Alburnus } \\
\text { filippii }\end{array}$ \\
\hline Kırmızı Köprü on Kağızman Road & $0 / 69$ & $0 / 64$ & $0 / 2$ & - \\
\hline Aksu Village in Susuz & $0 / 28$ & $0 / 2$ & - & - \\
\hline Akçalar on Arpaçay Road & $0 / 8$ & - & - & - \\
\hline Telek Village in Arpaçay & $1 / 68(1.5 \%)$ & $0 / 9$ & $7 / 16(43.8 \%)$ & $0 / 10$ & - \\
\hline Total & $1 / 173(0.6 \%)$ & $0 / 75$ & $7 / 18(38.9 \%)$ & $0 / 10$ \\
\hline$* \times / n$ : Number of fishes infected with L. intestinalis plerocercoids/Number of examined fishes & - \\
\hline
\end{tabular}


Therefore, both freshwater and sea fishing are common worldwide. The most important point in the consumption of fish is to get healthy fish. Parasites are the main factor affecting fish health and breeding. Parasites prevent fishes from growing properly and result in weak and powerless fishes. Moreover, these parasites cause health problems even in human beings if consumed. One of these parasitic diseases is ligulosis caused by $L$. intestinalis plerocercoids (1). There are many factors that affect the prevalence of ligulosis infection in freshwater fish worldwide and in Turkey. These are diet, age and sex of fish, length of plerocercoids, and intermediate and final host organisms. In particular, the rate of getting infected with parasites is related to variations in the diets and habitats of fishes in streams $(5,9)$. In this study, the most significant result is that $B$. plebejus lacerta found in the Kars stream was heavily infected with $L$. intestinalis at a rate of $38.9 \%$. Additionally, compared with other species of infected fishes, B. plebejus lacerta was detected in a greater number of plerocercoids. It is thought that the reason why $B$. plebejus lacerta infected widely may be the result of the nutritional and habitat characteristics of these fish. Because these fish species adapt to swim and feed on the bottom of streams. Therefore, it is estimated that the first intermediate host water fleas such as Cyclops sp. and Diaptomus $\mathrm{sp}$. of $L$. intestinalis are widely eaten by $B$. plebejus lacerta. It was also concluded that gulls in the Kars stream can be the main host in the biological development of $L$. intestinalis. Therefore, new research must be performed on gulls living in the Kars plateau, which is approximately $1800 \mathrm{~m}$ above sea level, to determine the prevalence of $L$. intestinalis.

It is reported that factors such as season, temperature, and a slight wave or shallow water affect the prevalence of $L$. intestinalis. It is mentioned that the low temperature of water slows down the speed of development of this parasite and sometimes even stops the development $(5,9,15)$. With the results of these studies held in our country and worldwide, it is concluded that the prevalence of $L$. intestinalis infection on fish in our country was lower at a rate of $2.6 \%$ than that in other countries $(2,4,5,8-12$, 15-22). Parasitic diseases cause important health and economic problems in farm animals in this region, which has the highest-altitude settlement in Turkey. In addition, ligulosis in freshwater fishes living around Erzurum has been reported (23). The low rate of $L$. intestinalis prevalence may be the result of the fact that this study was performed between April and July and low temperature of water. Additionally, the highest level of $38.9 \%$ of the prevalence of $L$. intestinalis on $B$. plebejus lacerta is found to be remarkable. L. intestinalis was found on 20 fish species in 32 different localities in Turkey (11). However, L. intestinalis infection was not observed for C. capoeta and B. plebejus lacerta (13).

\section{CONCLUSION}

In this study, the existence of $L$. intestinalis plerocercoids in freshwater fishes in the Kars stream and its tributaries has been reported for the first time. The prevalence of this parasite in freshwater fishes has been calculated in light of this data. Considering the geographical location and meteorological condition of the Kars plateau, ligulosis cases have been encountered in rivers located in the Kars plateau.
Ethics Committee Approval: Not required in this study.

Informed Consent: Not required in this study.

Peer-review: Externally peer-reviewed.

Author Contributions: Consept - M.Ö.A.; Design - M.Ö.A., M.Y.; Supervision - M.Ö.A; Funding - M.Ö.A., G.T.T.; Materials - M.Ö.A., G.T.T.; Data Collection and/or Processing - M.Ö.A., M.Y., G.T.T.; Analysis and/or Interpretation - M.Ö.A., M.Y.; Literature Review - M.Ö.A., M.Y., G.T.T.; Writer - M.Ö.A.; Critical Review - M.Ö.A., M.Y.

Conflict of Interest: No conflict of interest was declared by the authors.

Financial Disclosure: The authors declared that this study has received no financial support.

Etik Komite Onayı: Etik kurul raporu gerekli değildir.

Hasta Onamı: Hasta onamı gerekli değildir.

Hakem Değerlendirmesi: Dış Bağımsız.

Yazar Katkıları: Fikir - M.Ö.A.; Tasarım - M.Ö.A., M.Y.; Denetleme M.Ö.A.; Kaynaklar - M.Ö.A., G.T.T.; Malzemeler - M.Ö.A.; G.T.T.; Veri Toplanması ve/veya işlemesi - M.Ö.A., M.Y., G.T.T.; Analiz ve/veya Yorum - M.Ö.A., M.Y.; Literatür taraması - M.Ö.A., M.Y., G.T.T.; Yazıyı Yazan M.Ö.A.; Eleştirel Inceleme - M.Ö.A., M.Y.

Çıkar Çatışması: Yazarlar çıkar çatışması bildirmemişlerdir.

Finansal Destek: Yazarlar bu çalışma için finansal destek almadıklarını beyan etmişlerdir.

\section{REFERENCES}

1. Çiloğlu A, Bişkin Z. Balıklarda Görülen Parazit Hastalıkları: Respiratör Sistem, Deri ve Bağ Dokularda Cestod ve Nematod Hastalıkları. Özcel MA, editor. Veteriner Hekimliğinde Parazit Hastalıkları. İzmir: Meta Basım Matbaacılık Hizmetleri, Turkiye Parazitol Dern Yay No. 24, 2013. p. 1426-9.

2. Hajirostamloo M. The occurence and parasite-host of Ligula intestinalis in Sattarkhan Lake (East Azerbaijan-Iran). J Anim Vet Adv 2008; 7: 221-5.

3. Toparlak M, Tüzer E. Veteriner Helmintoloji. İstanbul: İstanbul Üniv Yayın No: 5064, 2000.

4. Akmirza A. The effect of Ligula intestinalis L. plerocercoid on the growth of bitterling (Rhodeus amarus Bloch, 1782). J Black Sea/ Mediterranean Environment 2007; 13: 155-60.

5. Brown SP, Loot G, Teriokhin A, Gue'gan JF. Host manipulation by Ligula intestinalis: A cause or consequence o parasite aggregation. Int J Parasitol 2002; 32, 817-24. [CrossRef]

6. Szalai AJ, Yang $X$, Dick TA. Changes in numbers and growth of Ligula intestinalis in the Spottal shiners (Notropis hudsonis), and their roles in transmission. J Parasitol 1989; 75: 571-6. [CrossRef]

7. Taylor M, Hoole D. Ligula intestinalis L. (Cestoda) an ultrasuctural study of the cellular response of roach fry, Rutilis rutilis to an unusual intramuscular infection. J Fish Dis 1989; 12: 523-8. [CrossRef]

8. Dörücü M, İspir Ü. Keban Baraj Gölü'nden avlanabilen balık türlerinde iç paraziter hastalıkların incelenmesi. Fırat Üniv Fen ve Müh Bil Derg 2005; 17: 400-4.

9. Demirtaş M, Altındağ A. Terkos Gölü'ndeki bazı balıklarda (Cyprinidae) Ligula intestinalis plerocercoid L., 758 enfeksiyonunun mevsimsel dağılımı. Yüzüncü Yı Üniv Vet Fak Derg 2011; 22: 147-51.

10. Ergönül MB, Altındağ $A$. The occurrence and dynamics of Ligula intestinalis in its cyprinid fish host, tench. Tinca tinca, in Mogan Lake (Ankara, Turkey). Vet Med Czech, 2005a; 50: 537-42. [CrossRef] 
11. Innal D, Keskin N, Erk'akan F. Distribution of Ligula intestinalis $(L)$ in Turkey. Turk J Fish Aquat Sci 2007; 7: 19-22.

12. Özbek M, Öztürk MO. Kunduzlar baraj gölü (Kırka, Eskişehir)'nde yaşayan bazı balıkların Ligula intestinalis plerocercoid L.,1758 enfeksiyonu üzerine araştırmalar. Turkiye Parazitol Derg 2010; 34: 112-117.

13. Turgut E, Develi N, Yeşilayer N, Buhan E. Seasonal occurrence of Ligula intestinalis infection in cyprinids from Almus Dam Lake (Turkey). KSU J Nat Sci 2011; 14: 9-11.

14. Kuru M. Türkiye içsu balıklarının son sistematik durumu. Gazi Üniv Gazi Eğit Fak Derg 2004; 24: 1-21.

15. Ergönül MB, Altındağ $\mathrm{A}$. The effects of Ligula intestinalis plerocercoids on the growth features of tench. Tinca tinca. Turk J Vet Anim Sci 2005b; 29: 1337-41.

16. Innal D, Keskin N. The infection of European Chub (Leucissus cephalus L.,1758) with Ligula intestinalis plerocercoids in Çamkoru Lake (Turkey). J Anim Vet Adv 2006; 5: 108-10.

17. Korkmaz AS, Zencir O. Annual dynamics of tapeworm, Ligula intestinalis parasitism in tench (Tinca tinca) from Beyşehir Lake, Turkey. J Anim Vet Adv 2009; 8: 1790-93.
18. Kurupınar E, Öztürk MO. Mevsimsel değişime ve boy büyüklüğüne bağlı olarak Leuciscus cephalus I.'un (Örenler Baraj Gölü, Afyonkarahisar) helmint faunası üzerine bir araştırma. Turkiye Parazitol Derg 2009; 33: 248-53.

19. Tekin-Özan S, Kır I, Ayvaz Y, Barlas M. Beyşehir Gölü Kadife Balığı (Tinca tinca L., 1758)'nın parazitleri üzerine bir araştırma. Turkiye Parazitol Derg 2006; 30: 333-8.

20. Weliange WS, Amarasinghe US. The occurrence of cestode Ligula intestinalis (Linnaeus) from attentive carplet Amblypharyngodon melettinus (Valenciennes) in Sri Lanka. Asian Fish Sci 2001; 14: 95-9.

21. Xianghua L, Zhixin L. Distribution of ligulid tapeworms in China. J Parasitol 1987; 73: 36-48. [CrossRef]

22. Yıldız K. Kapulukaya baraj gölündeki Kadife Balıkları'nda (Tinca tinca) helmint enfeksiyonları. Turk J Vet Anim Sci 2003; 27: 671-5.

23. Arslan MÖ, Kara M, Temur A, Altun SK, Küçükkalem ÖF. The evaluation of parasitic diseases in farm animals in North-Eastern Anatolian Region of Turkey. Kafkas Univ Vet Fak Derg 2008; 14: 31-5.[CrossRef] 